\title{
THE RISE OF INTERNET OF THINGS (IOT) AND ITS APPLICATIONS IN FINANCE AND ACCOUNTING
}

\section{DOI: 10.17261/Pressacademia.2019.1139 \\ PAP-IFC- V.10-2019(7)-p.32-35}

\section{Nurgun Komsuoglu Yilmaz ${ }^{1}$, Hulya Boydas Hazar ${ }^{2}$}

${ }^{1}$ Istanbul Aydin University, Department of Business Administration, Istanbul. nurgunyilmaz@aydin.edu.tr, ORCID: 0000-0002-9050-9796

${ }^{2}$ Istanbul Aydin University, Department of Business Administration, Istanbul. hulyahazar@aydin.edu.tr, ORCID: 0000-0002-7115-1899

\section{To cite this document}

KomsuogluYılmaz, N,,Boydas Hazar, H., (2019). The rise of internet of things (loT) and its applications in finance and accounting. PressAcademia Procedia (PAP), V.10, p.32-35.

Permemant link to this document: http://doi.org/10.17261/Pressacademia.20199.1139

Copyright: Published by PressAcademia and limited licenced re-use rights only.

\begin{abstract}
Purpose- The purpose of this study is to analyze the usage of internet of things (IoT) on finance and accounting. Internet of things refers the interconnection between devices via internet including mechanical and digital objects. The advancements including internet, wireless communication, microelectromechanical systems (MEMS) and radio frequency identification (RFID) created a world of interconnected devices, with loT this interconnection covers everyday objects. In this study it is examined the areas where loT can be used to facilitate finance and accounting.

Methodology- In this study a descriptive research approach has been followed. In this research, it has been summarized the relevant sources of literature from a critical point of view; it has been reviewed main concepts and aimed to explain the concept with a finance and accounting perspective.

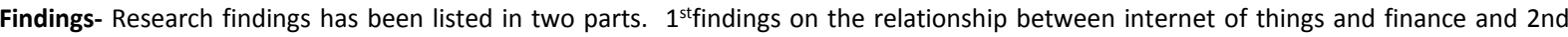
findings on the relationship between internet of things and accounting. In both business branch, internet of things has a wide area of research.

Conclusion- As a result of the study, it was evaluated that the concept of Internet of Things, which symbolizes the communication of objects used in daily life via internet, can have a wide range of usage in the field of finance, primarily in banking, and will also have an effect on increasing the level of automation in accounting activities through the data transferred directly from the objects.
\end{abstract}

Keywords: Internet of things, finance, accounting

JEL Codes: L68, G10, M41

\section{INTRODUCTION}

The Internet of Things (IoT) is based on network of devices capable of interacting and communicating with each other. Recent years, with the development of technology, the internet of things is used for prevention of environmental pollution, health data collection, prevention of obesity and control of smoking, effective agricultural systems, rapid community aid in disasters, transportation, solutions to energy problem and contribution to clean energy generation and production processes.

Physiological data can be collected and treated without any pain to the patient through wireless sensors and sensors that can be placed on the patient or placed on his / her body away from the hospital environment and at home. (Aktaş, Ceken \& Erdemli, 2014).

The main elements of Smart Environments are fire prevention conditions and flammable gases for the identification of risky areas, soil moisture, vibration and ground density monitoring of possible flood, avalanche and landslide disasters in advance, especially in the areas along the fault line to evaluate the early earthquake detection systems (Görkem\&Bozuklu, 2016). In addition, smart home system and smart city system can be given as an example of the use of technology. Also, efficiency is provided by smart energy distribution networks and energy storage systems (Amin \& Wollenberg, 2005)

The use of this technology not only makes life easier and improves quality of life, but also reduces cost and supports productivity.

One of the objectives of the Internet of Things is to bring online devices such as sound, image receivers, smoke detectors, household appliances, online with technology. Another revolutionary change aimed at the Internet of Things is the harmony of the network of devices, which makes each device accessible from the Internet (Doyduk \& ,2017). 
In addition to these features, it can be attracting for a financial institution to recognize its customer and offer personal loan and deposit interest rates or reward points. IOT via bank credit card customer's value of their asset, collect their spending habits and their periodic income (Joshi, 2019).

In the field of accounting and auditing, the use of loT ensures time-saving and accurate information flow, particularly in auditing and inventory management. As the information is collected continuously, the auditor is always informed about the operations of the company. Inventory items will be self-managing objects with intelligent internet systems. Inventory management system will provide competitive advantage to the company since it controls itself, decreasing human error and using time efficiently.

Inventory management system with loT is a process. This process begins from the procurement stage and lasts until the product is delivered to the end consumer. Raw materials needed for production and the production process can be monitored with this system, including informing customers via the internet. The bookkeeping of the related transactions can be integrated into this process. The records that are created by the system can be transferred to the company's accounting system and monitored continuously (Erturan \& Ergin, 2017).

\section{LITERATURE REVIEW}

The concept "Internet of Things-loT" first used by Kevin Ashton from MIT in a presentation made in P\&G in 1999 (Ashton, 2009). In the past 20 years, it has found a wide area of research and development, especially by the technology companies which are interested in designing and producing internet of things enabled devices. As mentioned in the study, ten years ago main communication form on the Internet was human to human (Tan \& Wang, 2010). But today many objects have their own method of identification and have their own addresses. It means these objects can be interconnected.

The Internet of Things (IoT) is a new technology and way to linking devices. Data is transmitted between different physical objects that are at different places. This data can be transformed and used as information(Kumar \& Raza, 2017) in many ways to facilitate humans' lives. The huge impact of this model on daily lives is due to the convergence of a variety of technologies and communications solutions (Atzori, Lera, \& Morabito, 2010)

On software testing help web site (https://www.softwaretestinghelp.com/best-iot-examples, 2019), powerful internet of things examples from real life have been listed as: "IoT Sensors, IoT Data Analytics, loT Tracking and Monitoring System, loT Connected Factory, Smart Supply Chain Management, Smart Barcode Readers, Smart Grids, Connected HealthCare System, Smart Farming". IoT sensors are RFID and MEMS enabled microchips attached to devices to share necessary data with other devices. loT data analytics is used to create more powerful insights. IoT monitoring and tracking systems are systems used to track and monitor people and goods in the long range by using GPS, RFID, MEMS and 4G, 5G connection enabled systems. IoT connected factories are production facilities where many interconnected machines work together in harmony by sharing their data with each other. Smart supply chain management symbolizes using interconnected devices including transports in supply chains to make them work in a more effective collaboration. Smart barcode readers can be defined asloT enabled barcode readers to facilitate managing inventory and stock level for companies.

Gong (2016) researched the potential of IoT as a tool of marketing. In his study, he mentioned that more than half of the most important marketers around the world believe that loT will play an important role on marketing landscape by 2020 . In their study, Nguyen \& Simkin (2017) researched the future loT trends and the implications for marketing. Gao \& Bai (2014) used technology acceptance model and analyzed the factors influencing consumer acceptance of IoT. Jara, Parra, \& Skarmeta (2012) investigated the subject with a Marketing 4.0 perspective.

Some of the studies on internet of things related to business management are mentioned above. As it is seen from these studies, loT is effectively used in financial transactions and in accounting areas. Main focus of our study is to investigate the usage of this technology in these two business functions, namely accounting and finance.

\section{RESEARCH METHODOLOGY AND FINDINGS}

In this preliminary research, a descriptive research approach has been followed. Since the research question is "what are the areas of use for loT in accounting and finance?", a qualitative approach has been used to interpret the secondary data on the research subject. Between researches, there is an ongoing argument on the value of quantitative vs. qualitative research design, and certain remarks have targeted descriptive research as being less pure than traditional experimental, quantitative designs (AECT, 2001).

From car insurance to home-owner insurance, telematics (measuring the use of sensors) can detect events such as injuries and accidents when they occur and help predict and measure losses when a customer files an insurance claim. As loT devices are becoming more prevalent in mobile devices, wearable technologies and other forms, the financial services industry has the opportunity to gather actionable, business-relevant data (when complying with regulations and privacy policies) (Acadiatech, 2019)

Uses of IoT in Banking may provide the attributes below (Digiteum, 2019)

- Wealth management personalization

- Improved payment security

- Transaction automation

- Improved transparency

- Optimized capacity management

- Voice assistants 
If a face recognition system is used, the bank's customers are recognized as soon as they come into the branch. With such a system, it is possible to measure the risk and to anticipate the probable reasons of the bank visit. If the visit is related to the mortgage or insurance, the risk level can be measured and the insurance premium can be calculated(CSO, 2019)Ability to predict the customer's financial requests and the related risk levels in real time will enable banks to offer customer-based interest rate alternatives and personalized financial instruments.

The concept called the internet of things (IOT) refers to tangible assets which are connected to the internet and can communicate with each other. The devices transfer information across networks in real time. Accounting is increasingly influenced by the loT technology. The communication of devices in real time has potential benefits and challenges. IoT provides abundant amount of new data. By the end of 2018, it is predicted that 20 billion devices are connected globally (Newman, 2018). However, reliability of internet data is a challenge. It is crucial to differentiate the correct data among the many, when it comes to use them in decision making. Another challenge is to create new accounting models which can incorporate information coming from sensors of billions of devices.

IoT has changed the way we do business today. It has led to numerous advancements in accounting. The loT may help accountants in the following areas:

- $\quad$ Providing Data for Business Models

- Asset Management

- Inventory Management

- Billing Services

- Auditing

- Budgeting

- $\quad$ Providing Advice to Clients

\section{CONCLUSION, LIMITATIONS AND RECOMMENDATIONS}

The integration of technologies like loT and artificial intelligence with finance and accounting will help business activities to be done more effectively. This will increase productivity, precision and speed in transactions, reducing costs while ensuring customer satisfaction. Determining probable needs of bank customers by using artificial intelligence will provide customer-specific offers. As a result of the study it is possible to say that internet of things will play a huge role both in finance and accounting in the near future and will be an integral part of the two business functions.

This study is limited with the ideas in the literature and the perspectives of the researchers on the subject. One other limitation for the study is its aim to focus on two functions of the business: accounting and finance. Future researchers may conduct studies on other functions of business or may follow a combined approach for all functions of a business.

Mainly, loT technology finds its area of use as an end-user technology but its industrial applications is increasing day by day. Industrial loT is also a good research area for future researchers. Security and privacy issues play an important role with this type of technologies which use wireless connections. Further researches can be conducted to address security and privacy concerns on internet of things adaptation to industries and user-products.

\section{REFERENCES}

Acadiatech (2019). How loT is Impacting the Financial Services Industry [online] Available at: https://www.acadiatech.com/blog/how-iotis-impacting-the-financial-services-industry/(Accessed 28.10.2019)

AECT, (2001). What Is Descriptive Research?, The Handbook of Research for Educational Research and Technology.

Aktas, F., Ceken, C., Erdemli, Y. E. (2014). BiyomedikaluygulamalarıiçinNesnelerininternetiTabanlıVeriToplamaveAnalizsistemi. Tıptekno'14Tıp TeknolojileriUlusalKongresi, 25-28.

Amin, M. \&Wollenberg B. (2005). Toward a smart grid: power delivery for the 21st century, IEEE Power Energ. Mag., 3 (5), 34-41

Ashton, K. (2009). That 'internet of things' thing. RFID Journal. Available at: http://www.rfidjournal.com/article/print/4986 https://www.rfidjournal.com/articles/view?4986 http://www.rfidjournal.com/article/print/4986

Atzori, L., Lera, A., \&Morabito, G. (2010). The Internet of Things: A survey. Computer Networks. https://doi.org/10.1016/j.comnet.2010.05.010

CSO (2019). IoT and Financial Services: Back to the Future.What to Do Now to Prepare for and Leverage the Inevitable. [online] Available at: https://cyberstartupobservatory.com/iot-and-financial-services-back-to-the-future/(Accessed 28.10.2019)

Digiteum (2019). How loT is Changing Financial Services and Banking [online] Available at: https://www.digiteum.com/internet-of-thingsbanking-finances/(Accessed 28.10.2019)

Doyduk,HBB. \&Tiftik, C.(2017). Nesnelerininterneti: Kapsamı, GelecekYönelimiveişFırsatları̈̈çüncüSektörSosyal Ekonomi,2017,52 (3) :127147

Erturan, İ. E., \&Ergin, E. (2017). MuhasebeDenetimindeNesnelerininterneti: Stok Döngüsü. MuhasebeveFinansmanDergisi(75), s. 13-30. 
Gao, L., \& Bai, X. (2014). A unified perspective on the factors influencing consumer acceptance of internet of things technology. Asia Pacific Journal of Marketing and Logistics. https://doi.org/10.1108/APJML-06-2013-0061

Gong, W. (2016). The Internet of Things ( IoT ): What is the potential of the internet of things ( IoT ) as a marketing tool ? IBA Bachelor Thesis Conference. https://doi.org/10.1523/JNEUROSCI.2765-05.2005

Gorkem, L ,Bozuklu, M . (2016). Nesnelerininterneti: YapılanÇalışmalarveÜlkemizdekiMevcut Durum. GaziosmanpaşaBilimselAraştırmaDergisi , (13) , 47-68. Retrieved from https://dergipark.org.tr/tr/pub/gbad/issue/29709/319647

Jara, A. J., Parra, M. C., \&Skarmeta, A. F. (2012). Marketing 4.0: A new value added to the marketing through the Internet of things. In Proceedings - 6th International Conference on Innovative Mobile and Internet Services in Ubiquitous Computing, IMIS 2012. https://doi.org/10.1109/IMIS.2012.203

Joshi N. (2019) What are the opportunities for loT in the finance sector, https://www.allerin.com/blog/what-are-the-opportunities-for-iotin-the-finance-sector, (Accessed 28.10.2019)

Kumar, Dr \& Raza, Zahid. (2017). Internet of Things: Possibilities and Challenges. International Journal of Systems and Service-Oriented Engineering. 7. 32-52. 10.4018/IJSSOE.2017070103.

Newman, D., (2018). 6 ways loT will improve accounting. Sage Advice. [online] Available at: [https://www.sage.com/en-us/blog/iot-willimprove-accounting/] [Accessed 19 October 2019].

Nguyen, B., \&Simkin, L. (2017). The Internet of Things (IoT) and marketing: the state of play, future trends and the implications for marketing. Journal of Marketing Management. https://doi.org/10.1080/0267257X.2016.1257542

Software Testing Help (2019), 10 Powerful Internet of Things (loT) Examples of 2019 (Real-World Apps) [online] Available at: https://www.softwaretestinghelp.com/best-iot-examples, 2019/(Accessed 28.10.2019)

Tan, L., \& Wang, N. (2010). Future internet: The Internet of Things. Proceedings of the 3rd International Conference on Advanced Computer Theory and Engineering (ICACTE). 